\title{
Class Teachers, Subject Teachers and Double Qualified: Conceptions of Teachers' Skills in Early Foreign Language Learning in Finland
}

\author{
Kaisa Hahl"a, Maija Pietarila ${ }^{b}$
}

$\begin{array}{ll}\text { Received } & : \text { 12 February } 2021 \\ \text { Revised } & : 18 \text { May } 2021 \\ \text { Accepted } & : \text { 21 June 2021 } \\ \text { DOI } & : \text { 10.26822/iejee.2021.223 }\end{array}$

"Corresponding Author: Kaisa Hahl, Faculty of Educational Sciences, Department of Education

University of Helsinki, Helsinki, Finland. E-mail: kaisa.hahl@helsinki.fi ORCID: https://orcid.org/0000-0002-8703-4558

'Maija Pietarila

E-mail: maija.pietarila@helsinki.fi

ORCID: https://orcid.org/0000-0002-0733-8405

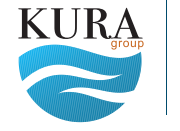

Copyright (C)

WWw.iejee.com

ISSN: 1307-9298

(c) 2021 Published by KURA Education \& Publishing. This is an open access article under the CC BYNC- ND license. (https://creativecommons.org/ licenses/by/4.0/)

\begin{abstract}
The shift to an earlier start in foreign language teaching in Finland took place nationwide in 2020. Both class teachers and subject teachers faced a new situation. They would be teaching children younger than before, or they would be teaching a completely new subject for them. This article examines teachers' conceptions of the skills and competencies, including required language skills, that are important for a teacher in early foreign language teaching. The data for this study were gathered through essays that teachers ( $n=44$, subject teachers, class teachers, and double qualified teachers) turned in as tasks during an in-service teacher training for early teaching of foreign languages. The essays were analyzed with content analysis. The findings show that teachers found it the most essential that early foreign language teachers have enthusiasm for the job and are able to inspire learners. They also considered it important that teachers focus on learners and the learning environment, as well as have skills for early years pedagogy. The teachers did not consider foreign language education or language skills as important as the other skills but yet wished for teachers to be able to communicate in the target language in the class.
\end{abstract}

Keywords:

Early Foreign Language Teaching, Class Teachers, Subject Teachers, Finland

\section{Introduction}

T here has been a trend to an ever-earlier start to foreign language teaching and learning in Europe since the 1990's (Enever, 2016). The decisions for lowering the starting age have often been made on the assumption that younger learners learn a new language better (e.g., Luz Celaya, 2012). However, currently there is little proof that an earlier start will provide the learner with better language skills than starting later (Muñoz \& Singleton, 2011; Pfenninger \& Singleton, 2017). The reasons are many. Among the reasons are that 
young learners are usually offered a minimal amount of teaching in the foreign language (Enever, 2015), the level of language skills by teachers varies (Unsworth et al., 2015), and teachers' skills to implement ageappropriate pedagogical solutions are sometimes lacking (Nikolov \& Mihaljević Djigunović, 2011)).

The shift to an earlier start in foreign language teaching in Finland, the context of this study, took place nationwide in the beginning of 2020 (Inha \& Kähärä, 2018). Before the change, both subject teachers (specialized in the language) and class teachers (generalists who teach at the elementary level) were offered in-service teacher training to enhance their competencies in teaching a foreign (or second) language to young children. Both groups of teachers faced a new situation. They would be teaching children younger than before, or they would be teaching a completely new subject for them. This article examines subject teachers' and class teachers' conceptions of the skills and competencies that are necessary for a teacher in early foreign language teaching, including teacher's language skills.

\section{Early Teaching of Foreign Languages}

Early foreign language teaching sets partly different requirements for language teachers when compared to teaching foreign languages to older students. When learners are so young that they do not yet read and write, the main input is through listening to the teacher using the language or hearing language from other sources, such as videos or audio files. Many researchers thus encourage teachers to use solely or mostly the target language in order to maximize learners' exposure to it (Enever, 2016; Mezzi, 2012).

One of the reasons why the Finnish government pushed for the early teaching of foreign languages was the understanding that young children learn languages very easily due to the so-called sensitivity period (Finnish Ministry for Education and Culture, 2018). The same reason has also been behind the decision to start earlier in many other countries (Enever, 2015). However, research on the sensitivity period does not explicitly support the claims of success, particularly when the question is about learning foreign languages in a school context instead of learning a second language in a home or daycare setting (e.g., Luz Celaya, 2012; Nikolov, 2009). It is rare that there is more than minimal exposure to a foreign language at school where the language is usually taught for only one or two lesson hours per week (Enever, 2015). Furthermore, prior research shows that sometimes any advantage that earlier starters gain is caught up by older starters - even within a few months (Dolean, 2015; Huhta \& Leontjev, 2020; Muñoz \& Singleton, 2011; Pfenninger \& Singleton, 2017).
However, there are advantages that young children may have over older learners; namely motivation, positive attitude and the willingness to engage in activities (Johnstone, 2009; Nikolov, 2009). These are aspects that can be capitalized on in teaching. In her research, Enever (2015) brings up five elements that are essential for successful early foreign language learning and that warrant particular attention. These are teacher expertise, learners' sustained motivation, continuity of learning, setting realistic aims, and outof-school learning.

Being exposed to a foreign language outside of school is known to have a positive influence on learning the foreign language. However, pinpointing the exact benefits has been difficult to prove with research (Enever, 2015; Pfenninger \& Singleton, 2017). Nevertheless, being exposed to the language through various channels and using it also outside the classroom will grant learners precious practice time. Out-of-school learning may take place without learners even realizing it or considering it studying. Thus, a pleasant and stress-free environment may be well suited to language acquisition. A study by de Wolf et al. (2017) even suggests that early foreign language learning is not beneficial without the support of outof-school exposure to the language.

Setting realistic aims for foreign language learning is important so that both teachers, learners and guardians know what (kind of) learning outcomes can be expected. It must be kept in mind that in minimal input instruction (such as 1-2 lesson hours weekly), the expected results must be reasonable and feasible within the limited exposure and learning time (Enever, 2015; Dolean, 2015). Continuity of learning a foreign language should be ensured so that students moving from one school or one school level to the next would be able to continue their language learning path at the right level (Enever, 2015).

Some skills that are not easily measurable or comparable in statistics might be overlooked when learners' progress is tested (Enever, 2015). Such skills are, for example, affective aspects including attitude, motivation and intercultural learning. These are skills that early foreign language teaching seems to affect positively. The provision of teaching a foreign language to young learners also differs from context to context, with different implementations of teaching and different numbers of weekly lessons (de Wolf et al., 2017). Thus, it is difficult to compare students' language attainment between contexts. A Dutch study showed that early starters (age 4) outperformed later starters (age 8-9) with "a marginal advantage" in oral fluency (de Wolf et al., 2017, p. 341). However, in many school contexts, such as in this study, starting the first foreign language is later than at the age of 4 . 
The elements that are the most central in terms of this article are teacher expertise and learners' sustained motivation. Teachers often have different educational backgrounds and competencies, and their language skills vary (Unsworth et al., 2015). Teachers do not always receive sufficient professional development before they start teaching a foreign language to young learners (Zhetpisbayeva et al., 2016). Teacher expertise for early foreign language teaching consists of both strong language skills and the ability to use ageappropriate teaching techniques and tasks (Enever, 2015). Teacher expertise can also be considered to include teachers' personal qualities, such as an ability to create rapport with students (Edelenbos et al., 2006). Nguyen (2016) calls this a mother or a caregiver role that teachers adopt to show affection and care to children. Teachers also need an ability to create a pleasant and invigorating classroom atmosphere (Edelenbos et al., 2006). Teachers can inspire learners with their artistic and creative abilities when they use movement, singing and facial expressions, and act out different roles (Nguyen, 2016).

Unsworth et al. (2015) found that young children who had teachers with a high language proficiency (above B2 in CEFR) scored better in vocabulary and grammar tests after two years of learning than those children whose teachers had a lower level of language proficiency (B2 or below). In fluent speech, we retrieve and combine various readymade 'lexical chunks' - language that consists of short phrases including words and structure (Mezzi, 2012). Teachers can teach actual language structures and grammatical constructions to older learners, whereas young learners do not yet possess sufficient cognitive skills to receive such instruction. Teachers need to provide young learners with plenty of opportunities to repeatedly hear and use correct forms of lexical chunks (Mezzi, 2012). That is why students should be exposed to authentic language that results from real acts of communication. Young learners learn the meaning of a new language more holistically by listening, imitating, and repeating (Pinter, 2017). In order to enhance young children's learning, teachers are advised to use their tone of voice, facial expressions, gestures, and movement to encourage the learners to guess the meaning of new words (Mezzi, 2012; Meriläinen \& Piispanen, 2019). Teachers who are fluent speakers of the target language will likely speak more target language in the classroom than teachers with a lower level of language skills. Teachers also need to know how to make their speech comprehensible and not too complicated so that it is at the appropriate level for the student group (Graham et al., 2017).

Learners' motivation and engagement are influenced, for example, by the kind of activities that the teacher selects and the nature of learner involvement in the activities (Edelenbos et al., 2006; Mezzi, 2012). Earlier studies show that young children are initially very motivated and have a positive attitude towards language learning (Enever, 2016). They are easily excited and engage willingly in various activities (Johnstone, 2009; Nikolov, 2009). In the beginning, young children are often introduced to language learning by games, storytelling, role-playing, drama and different sketches (Mezzi, 2012). It is important that the chosen methods are interactive, engaging and encouraging (Enever, 2015; Johnstone, 2009; Luz Celaya, 2012). However, learner motivation declines with age. The reasons are that the early years of using the fun approaches of singing and games are gradually changed to more demanding tasks of studying by reading, writing and memorizing vocabulary (Enever, 2016). Learners' attitudes to songs and games change with age, too, and thus teachers need to adapt to what fun and meaningful activities mean for different age groups.

\section{Foreign Language Teaching in Basic Education in Finland}

Teaching of foreign languages starts now in grade 1 (age 7) in Finland. Previously, the starting of the first foreign language was not until grade 3 (age 9) in most schools. This change became effective in January 2020 and from then on, all first graders start the first foreign language at the latest in the spring term of the first school year. The change in the starting age of the first foreign language was historical as it was through an addition of lesson hours without taking any away from other subjects. However, it is only one 45-minute lesson that all students are given in a week unless a municipality gives extra resources for it (e.g., the capital of Finland). One of the goals of lowering the starting age was also that students would be given opportunities to choose languages other than English and that the overall scope of Finnish people's language reserve would widen. However, it seems that those goals may not be realized as English is most often the only language that is offered for first graders. Students may have an opportunity (if schools offer it and if enough students choose it) to start their second foreign language in grade 4 or 5 . In grade 6, all students in Finnish-language schools start Swedish, the second national language in Finland, as another "foreign" language. In grade 8, students have their next opportunity to add another foreign language to their repertoire (Finnish National Board of Education, 2016). The statistics show that the number of students learning additional languages has dropped dramatically in the last two decades except for Spanish that has gained popularity as a new foreign language in Finland (Education Statistics Finland, 2020). 
According to the core curriculum (Finnish National Board of Education, 2016), the objective of foreign language teaching in Finland is to strengthen students' multilingual competence that comprises all the different language competence levels of students' home language(s), second, and additional languages. It aims to strengthen students' parallel use of different languages and increase their language awareness and understanding of themselves as multilingual speakers. Language education should support the development of students' cultural identities and increase their appreciation for linguistic and cultural diversity. Teachers are supposed to utilize diverse teaching methods and make room for joy, playfulness and creativity in learning (Finnish National Board of Education, 2016). The additions done to the Finnish core curriculum in relation to early foreign language learning emphasize the use of oral skills in everyday situations and the handling of topics in multifaceted ways (Finnish National Agency for Education, 2020).

The Finnish government started a Government Key Project for Languages in 2017, which focused on increasing and diversifying language teaching by offering resources to municipalities to organize regional experiments for early teaching of foreign languages. The aims of the key project have been simplified to three main focal points: integrating early foreign language learning into Finnish basic education at a much larger scale than before, providing students access to a wider language repertoire, and introducing students to a positive and encouraging attitude and approach to language learning (Inha, 2018a).

In Finland, foreign languages have usually been taught by subject teachers specialized in one to three languages. However, a class teacher, as a generalist teacher and qualified to teach any subject offered in the elementary school (first six grades of basic education), is also qualified to teach a foreign language. They are qualified even if they have no prior knowledge or education in the language subject. Class teachers may have other subjects as minors that they are qualified to teach also at the lower secondary level (the last three grades of basic education). These teachers (with a language as a minor) are referred to in this article as double qualified teachers. When early teaching of foreign languages was introduced through various projects funded by the government (Inha, 2018a; Inha \& Kähärä, 2018), different schools opted for different implementations, usually based on teachers' own interest. Sometimes it was a subject teacher, sometimes a class teacher who would teach a foreign language in the early grades, or sometimes lessons would be co-taught by a subject teacher and a class teacher (Hahl, Savijärvi, \& Wallinheimo, 2020). In general, all teachers faced a new situation. On the one hand, subject teachers were not used to teaching such young children who were not able to read and write yet. On the other hand, class teachers might not have taught a foreign language ever before. Thus, there was need for further training for all teachers.

So far there is limited research about early teaching of foreign languages in Finland, or about teachers' conceptions of teaching a foreign language to younger students than before. This qualitative study thus aims to fill this gap by examining teachers' conceptions of teacher's skills and competencies, including required language skills, in order to gain an understanding about the following questions:

1. What skills and competencies do subject teachers, class teachers and double qualified teachers consider important for a teacher in early foreign language teaching?

2. What (kind of) language skills do subject teachers, class teachers and double qualified teachers consider important in early foreign language teaching?

\section{Data and method}

The data for this qualitative study were gathered through essays that teachers turned in as assignments during an in-service teacher training for early teaching of foreign languages. The same in-service teacher training was offered to two groups of teachers, the first in autumn 2019 and the second in spring 2020, lasting about 5-6 months. The implementation of the second training had to be modified due to the worldwide Covid-19 pandemic, but the assignments remained the same. The assignments were completed in between full training days that were carried out as contact teaching (two out of four in the spring term as remote teaching) as well as shorter one-hourlong webinars. Each teacher turned in four separate essays. The participants read selected literature and watched short videos where an invited specialist shared her expertise and research done by scholars in early foreign language learning. The assignments also included questions that the participants answered in essay-type writing. The questions posed to the teachers related to the teachers' conceptions and approaches to supporting student learning and the use of various games and activities; what they considered important in teachers' language skills, and how they felt about their own language skills; what they considered the most essential skills and competencies for teachers to possess in early foreign language teaching; and what they wanted to develop in their own skills.

The participants were in total 44 teachers, of whom 18 were subject teachers (ST), 10 class teachers (CT), and 16 teachers who were double qualified as both class and subject teachers (CST). All of them signed a 
written consent to use their assignments for research. The majority of the teachers had already participated in early foreign language teaching, either through a program that their school had had in place for a longer period, or through a project that had been funded by the government since 2017 (Inha, 2018b). The essays were analyzed with thematic analysis (Braun \& Clarke, 2006) and coded with the Atlas.ti program. The analysis was carried out as an iterative process where the data were read through multiple times while looking for repetitive content that was labelled with themes. The similar themes and content were then grouped into larger categories. We present the findings in the next section as the final categories that we formed based on the themes raised from the data.

\section{Findings}

The findings of this study are presented here according to the research questions. First, we present the skills and competencies that the in-service teacher training participants considered important for a teacher to possess in early foreign language teaching, before moving on to the question about language skills.

\section{Important Skills and Competencies for a Teacher in Early Foreign Language Teaching}

The teachers of the in-service teacher training brought up many different professional skills and personal qualities that are important for a teacher to have when teaching a foreign language to young children. These skills and competencies are presented and discussed in the following, starting from those that were considered the most important by the teachers. We have divided the skills and competencies into the following categories:

- Enthusiasm and ability to inspire

- Focus on children and the learning environment

- Skills for early years pedagogy

- Skills for foreign language education

- Willingness to develop one's skills

- Ability to throw oneself in the job

- Using one's strengths

\section{Enthusiasm and ability to inspire}

The participants were overwhelmingly in agreement about the most important skills and competencies that a teacher should possess for early foreign language teaching. We have named the first of these categories as Enthusiasm and ability to inspire, and almost all teachers mentioned these competencies (100\% of ST, $94 \%$ of CST, $100 \%$ of CT). The participants emphasized it as the most essential that the teacher is enthusiastic and willing to teach a foreign language to young students. Simultaneously, the teacher should be able to inspire and motivate students to language learning through awakening a curiosity and excitement for learning a new language.

I think the most important skill, or an area of emphasis, is teachers' own inspiration and will to teach the early language. I feel that teachers' most important task is to motivate students and create a safe learning environment?' (Double qualified teacher 28)

These aspects were most often mentioned at the same time. Teachers' inspiration was seen contagious and necessary for promoting and maintaining students' motivation and interest at the same time. However, as the teacher below mentions, a teacher's own inspiration is not something stable, but it may need to be nurtured and reignited at certain intervals.

\begin{abstract}
I think it would be ideal for each teacher that their own attitude to the taught subject and subject area would be as positive as possible. It can be assumed that a subject teacher, who has chosen to study a particular subject, possesses motivation and knowhow to acquire and teach it. Motivation and inspiration are not stable states, however, and sometimes they might disappear and to find them again and strengthen them needs self-orientation and one's own development. (Subject teacher 29)
\end{abstract}

The teacher in the above quote also addresses the difference in the situation for subject teachers and class teachers. A subject teacher is an expert in the particular subject, but a class teacher has maybe never taught the subject before.

\section{Focus on children and the learning environment}

The second category combines several aspects of teachers' skills and competencies that are related to learners and the learning environment. The teachers mentioned that teaching must start from the young students and the teacher must be able to create a safe learning environment that also feeds students' courage as language users. Teachers need to know their students and their world and include children's ideas and their points of interest into teaching. All the subject teachers, double qualified teachers and class teachers mentioned at least some of these aspects as essential to teacher's skills and competencies.

I think the most important thing in early foreign language teaching is to get students inspired about foreign languages and cultures and arouse their own curiosity and motivation towards languages. For this to succeed, the teacher must be able to create a safe environment for understanding and speaking the language so that it does not cause fear for the future. Here the teacher has a big role so that s/he can provide the students with experiences of success even just from the courage of trying before they have necessarily even learned it yet. (Double qualified teacher 42) 
Group management skills are important in creating a safe and peaceful learning environment. These skills enable teachers to set limits and maintain order as well as carry out transitions in between tasks. A peaceful learning environment provides students with an opportunity to concentrate on the given tasks. Subject teachers have most often taught older children who are already used to being in school and who know the rules for behavior. On the contrary, class teachers teaching in grades 1 and 2 have the responsibility and experience of teaching young children the basic skills of being in school. This is perhaps the reason why class teachers were the ones to emphasize group management skills. As the teacher below expresses, classroom management skills are all the more important when group sizes are big and students diverse in their development levels.

Classroom management and organization skills are extremely essential with large student groups and different students (of very different levels). (Class teacher 06)

Subject teachers also brought up teachers' ability to be flexible according to the specific group of children. This competency was only seldom mentioned by class teachers or double qualified teachers. Flexibility was associated with teachers' ability to read different situations and, when necessary, adjust plans and activities on the go according to the needs of the learners.

A safe learning environment is also important so that students feel comfortable and encouraged to try speaking the new language without being afraid of making mistakes. Encouraging students to become confident language users was considered important by especially the double qualified teachers and subject teachers while half of the class teachers mentioned this. The encouragement to language use included urging students to become active in using and functioning in the foreign language from the start as well as offering them experiences that enabled the use of the language.

A good teacher encourages students and urges them to use even their small language skills bravely. In addition, the teacher helps to notice strengths and makes the learning objectives and their attainment explicit. This means, too, that self and peer assessment are practiced regularly with students. (Double qualified teacher 02)

A safe learning environment should also support students' sense of capacity to function in the foreign language. It was considered important that teachers both acknowledge students' strengths and provide them with plenty of opportunities for feelings of success.

\section{Skills for early years pedagogy}

All the class teachers and double qualified teachers (100\%) specified that it was important for early foreign language teachers to possess skills for early years pedagogy and be able to select age-appropriate and varied tasks. Almost all of the subject teachers (89\%) mentioned these skills as well. Being familiar with early years pedagogy includes possessing knowledge about young children's developmental stages and how they learn.

All teachers, despite their educational background,
must know age-appropriate pedagogy. Under-
standing age-appropriate matters is important.
Teachers' own understanding and will to make
teaching of high quality, plan diverse and motivating
lessons and obtain necessary knowledge and skills
are essential. (Subject teacher 36)

Teachers also mentioned practical solutions such as short and clear instructions and scheduling and alternating more peaceful and more active tasks in lessons. They talked about creating routines and selecting content with "less is more" understanding.

Right now I believe that my prejudice about class teachers was wrong. It might have been a better option to choose 'less is more' thinking in an English lesson and group management by a class teacher than subject teachers jumping into the deep end for the first time who had no previous experience of action-based tasks and young children's energy. (Subject teacher 07)

Some teachers also admitted (as above) that, before the training, they had been biased against teachers with a different educational background. Thus, the training had also helped teachers to become more open and receptive to other teachers' skills and talent. Although subject teachers often have a stronger command of the foreign language, some yet lack skills and experience of dealing with very young children and selecting suitable teaching activities and tasks.

\section{Skills in foreign language education}

It was notable that the number of teachers (50\% of ST, $50 \%$ of CST, $20 \%$ of CT) who considered skills specifically in foreign language education important in early foreign language teaching was much lower than in the earlier categories. However, some teachers, as the one in the quote below, emphasized that it is essential that language teachers also have knowledge of how to best teach foreign languages to young children.

I think it is very important in early foreign language teaching that the teacher masters both foreign language and early years pedagogies. [...] The teacher should be able to speak fluently so that children get proper exposure to the language and have knowledge of foreign language pedagogy so that s/he can plan teaching as an efficient and 
beneficial entity. However, it is also important that the teacher can take into account her/his learners' age and developmental stage. (Subject teacher 35)

This teacher highlighted the importance of knowledge in both foreign language education and early years pedagogy, but also strong language skills. It was also recommended by many of the teachers that initial class teacher education would have studies in foreign language education (which may be optional but are not compulsory at the moment).

\section{Willingness to develop one's skills}

Almost three quarters of the subject teachers (72\%) mentioned that it was important that a teacher is willing to develop her/his skills and is open to new ideas. Meanwhile, a little over a third of double qualified teachers (37\%) and class teachers (40\%) mentioned this aspect as important. This aspect included teachers' will to develop their teacherhood and/or language skills, for example, through in-service teacher training. The will to develop oneself consisted also of being open, possessing a preparedness to challenge used practices and to try something new..

It is worth for a teacher to aim to develop continuously through peer support and self-studying. Peer support, support by conversation, and interaction based on brainstorming can be found in social media groups in addition to one's own colleagues. There is plenty of in-service training available, too, and it is worth it to challenge oneself to step outside of one's comfort zone. That is when new opportunities open up to widen one's own image of being a teacher and a perspective to one's own teacherhood. (Subject teacher 29)

As the teacher in the above quote mentions, development can be gained through formal inservice teacher education, but also more informally from colleagues in one's own school or online, through discussions, sharing of ideas and material, and peer support. Some teachers also called for more coteaching or joint planning sessions between teachers. They mentioned that if there were more collaboration between teachers in the schools, each type of teacher could share their expertise and educate the others.

Some teachers also mentioned the necessity to have inspiration for teaching a foreign language to young learners in order to be willing to develop - especially if early foreign language teaching is new for them.

I [think] that students can certainly see it if a teacher is not excited about teaching the language. I think schools should pay attention to this. If a class teacher says that $s /$ he is not willing to teach a foreign language, it would be important to listen to the teacher and, in particular, to the reasons why the teacher does not want to teach and take it seriously... Students can sense it quickly if a teacher is not interested in teaching the language. I would be personally more worried of a situation where a teacher is forced to teach a foreign language than, for example, if the teacher's pronunciation is lacking. A motivated teacher is willing to learn new things and find ways to go around her/his shortcomings. (Subject teacher 18)

The above quote brings up an issue that worried some teachers: sometimes a (class) teacher is made to teach a foreign language without having competence for it or without having a desire to teach it. It was considered essential that teachers could choose themselves whether they wanted to teach a foreign language in the early grades or not. This is, after all, a new subject for many teachers. It was felt that if teachers are motivated to take on a new challenge, they will also be motivated to develop themselves to do the job well.

\section{Ability to throw oneself in the job}

Half of the subject teachers (50\%), and more than a third of double qualified teachers (44\%) and class teachers (40\%) mentioned teacher's ability to throw themselves in bravely in early foreign language teaching. This category includes an ability and courage to throw oneself in plays, games and action, and act silly and have fun without being constrained by the fear of acting foolish. It is a way to meet students at their age level.

Early foreign language teaching is by nature functional and consists of a lot of plays and songs, which requires a whole-hearted attitude to throw oneself into teaching and often functioning outside of one's own comfort zone. A good teacher gives their students an important model that one does not need to be flawless, and you can view yourself with kind humor. (Double qualified teacher 40)

One of the class teachers wrote that being able to throw oneself in bravely can also help if a teacher does not possess strong language skills.

When tutoring other teachers, I have noticed that several teachers are ready to throw themselves in the job and many have a great amount of courage although their language skills are not at the level of an English teacher. I think being a good teacher includes in fact one's ability to throw oneself in and even if things do not always go perfectly right, you can still speak English. (Class teacher 09)

Starting early foreign language teaching has also influenced some subject teachers' other language teaching in a positive way. Some mentioned how they have now more courage to try out new things with older learners as well.

I enjoy early foreign language teaching and its planning. With small children, you must be genuinely engaged and present in the lesson. Your every cell is engaged in the early teaching. Furthermore, 
teaching a foreign language to small children has enriched my teaching, because I am much braver to include action-based tasks in every lesson, even with older students. (Subject teacher 04)

Starting to use action-based tasks in language learning might be a substantial change from normal practices for subject teachers. Teaching foreign languages in Finland is often book-based with limited communicative activities (Harjanne et al., 2017).

\section{Using one's strengths}

The last of the categories and another quality considered important by half of the subject teachers (50\%) and about a third of double qualified teachers (37\%), but rarely mentioned by class teachers (20\%), was teacher's own strengths. Using one's strengths was associated with the understanding that it depends on each teacher on what makes her/him a good teacher for early foreign language teaching.

Nowadays a teacher is met repeatedly with external requirements and may, under continuous pressures for development and change, doubt the adequacy of their own skills. It is important to remember that there is not only one "right" way to teach but each teacher works with their own personality and brings in their own strengths and experiences. I am sure that every teacher aims to be a good teacher in their own way. (Subject teacher 38)

As the teacher above writes, there are many right ways to implement good teaching. It was considered important for teachers to use their own personality in teaching and reflect on the strengths they have that can be harnessed in teaching.

\section{Language Skills for a Teacher in Early Foreign Language Teaching}

The participants were asked specifically to consider what kind of language skills are necessary for a teacher to possess in order to teach a foreign language to young children. We have divided the different skill areas raised from the teachers' essays into the following categories:

- Communication in target language

- Courage to speak and trust in one's language skills

- Basic grammar and pronunciation

- Correctness and development of language skills

\section{Communication in target language}

The majority of the teachers (83\% of ST, $88 \%$ of CST and $90 \%$ of CT) felt that communication in general in the target language and communicativeness were the most important when considering teacher's language skills for early foreign language teaching. The participants felt that if teachers are too focused on error-free language, it hinders the naturalness of the language and even scares teachers away from communicating in the target language.

\begin{abstract}
Of course, teacher's language skills matter, but native speakers do not either always speak the language perfectly or know how to pronounce all the words correctly. So, communicativeness goes before grammatical correctness. Of course, teachers should aim at good and right language, but it must not be a hindrance or cause fear of teaching a foreign language. Each one of us can learn new things and no one is so perfect in their language skills that they don't make any mistakes. Children might in fact feel braver and safer to also make mistakes, if the teacher dares to be fallible and sometimes makes mistakes. (Double qualified teacher 08)
\end{abstract}

Some of the teachers, as the one above, also mentioned that the teacher can set a right example to the students if they use the target language despite some weaknesses in their language skills. They can show to the students that one does not need to be a "perfect" speaker to use the new language (as we all make mistakes even in our first language) and that it is natural and acceptable to make mistakes or to not always find the right word. However, the teachers considered it important that a language teacher would use as much of target language as possible.

\section{Courage to speak and trust in own language skills}

Many of the teachers mentioned that it is important to trust in one's own language skills in order to have the courage to speak the language in the class. Two thirds of the double qualified teachers and half of the subject teachers mentioned this as essential. Only three class teachers (30\%) mentioned this aspect.

As a language teacher I find all language competence utmost important, and I think in a language class the teachers should use the target language as much as possible. I have often encouraged my colleagues to speak the foreign language. (Subject teacher 35)

Some of the teachers brought up the fact that in some schools, a teacher who has not previously taught the language and does not speak the language well, would yet be made to teach it. These teachers were encouraged to start learning and speaking the language alongside with the students.

I think a teacher can throw herself into the role of a student and learn pronunciation together with the children. For example, a puppet, who speaks in the voice of the recording, could be in the role of the teacher. I still hope, however, that every language teacher would find the courage to speak the language themselves. (Double qualified teacher 03) 
For those teachers, who have not studied the foreign language, used their English (or other language skills) in years, or do not possess good language skills, having to start to teach it anyway might feel insurmountable. Thus, the teachers felt that support from the school community and participation in in-service training are highly needed.

\section{Basic grammar and pronunciation}

Most of the teachers felt that basic language skills were important. They thought a language teacher should have good pronunciation of the language and/or knowledge of at least basic grammar (72\% of ST, $69 \%$ of CST, $50 \%$ of CT). Young students do not yet read and thus their language input comes either through different audio or video material, but also relies largely on the teacher to be a model for them in pronunciation.

It would be good for a language teacher [in early language teaching] to know how to pronounce the language correctly at least in general. One can cope with a smaller vocabulary, but wrong models of pronunciation get easily stuck in the child's mind. (Double qualified teacher 17)

However, some teachers commented that a teacher can supplement her/his lack of language skills with widely available recordings of native speaker speech

Fortunately, it is extremely easy to offer children good models of pronunciation and error-free speech with native speaker recordings. (Subject teacher 11)

Many of the teachers also discussed English as a lingua franca and its multiple variations. Although different Englishes and all languages should be appreciated, some teachers yet worried about what non-standard models of pronunciation would do to the children. There was also a concern that not all children are exposed to the foreign language outside of school and at home. Therefore, there would be a greater need for exposure and support in the school.

Nowadays there are so many speakers of different Englishes in the world that different kinds of "rally English" are allowed. I think this is all in all a slightly difficult question in relation to the early teaching of languages, because children should learn right pronunciation from the start. All children do not necessarily have models for English around them through the media or their homes. (Subject teacher 01)

Traditionally, the teaching of foreign languages has started from grade 3 in Finland and usually the languages have been taught by subject teachers specialized in the particular language. There was a worry among some teachers that early foreign language teaching is not valued in the same way as foreign language teaching from grade 3 on, if it is taught by a class teacher who does not have sufficient language competence.

\begin{abstract}
Class teachers, sometimes regardless of their skills, might have to teach a foreign language in the early grades. I still wish that in the future, students would be given the "best possible" teaching. It is wrong to think that the language subject in grades 1 and 2 is less valuable than from grade 3 on. Because in early foreign language teaching the focus is largely on listening to and speaking the language, it should be "quite right". I mean by this that if the teacher lacks the articles or is missing simple grammar, the situation is challenging. Students learn by listening to the language the first couple of years. If it has a lot of errors, I can imagine that students will experience fossilisation. (Double qualified teacher 31)
\end{abstract}

Fossilization refers to a process in which a learner is not able to attain target language accuracy in a foreign language but learns a deviant form of, for example, pronunciation or grammar. Incorrect language forms become a habit and cannot be easily corrected (e.g., Han, 2013). Some teachers were particularly worried about repetitive grave errors that students might be exposed to if teachers lack good pronunciation and basic grammar. They worried that it would be challenging for other teachers later to try help the learners rid themselves of the wrong forms and learn correct language forms.

\section{Correctness and development of language skills}

Although the teachers were mostly very lenient about the level of language skills needed for early foreign language teaching and considered communication in general more important, a third of the teachers (of each teacher type) yet mentioned that a language teacher should aim at as good and error-free language as possible.

It is good to aim at the correct pronunciation and grammar as exactly as possible, but communicativeness is yet more important. (Subject teacher 34)

The participants mentioned that teachers should also upkeep and develop their language skills - in the same way as they should any other skills and competencies that are part of their work. A class teacher (below in the quote) discusses her perspective to English accents. Although she wants to work on improving her English pronunciation and lose her "Finnish accent," she does not think her foreign accent should deter her from teaching English.

In my own English teaching, I would still like to develop my pronunciation to be better and phonetically more correct, and get rid of my Finnish accent. Although I don't feel like the accent is a hindrance to teaching English. In fact, I believe that it is good for children to hear as many different kinds of speakers as possible. (Class teacher 06) 
For many, strong language skills were not as important as other aspects of teachers' skills and competencies.

I think a teacher's strong language skills are not enough if teaching does not start from the young learners. If the teacher has a sufficiently good command of the language to feel her/himself confident in using it, then experience from early years teaching is more important. Every teacher needs to take care of maintaining and updating their language skills. I also hope there will be funding for such in-service education. (Class teacher 33)

In general, teachers considered their own motivation and eagerness to teach a foreign language to young students and focusing on the students more important than strong language skills.

Another aspect important to teaching foreign languages, but seldom mentioned by the teachers in their essays, was the knowledge of cultural content associated with the foreign language.

\section{Discussion and conclusions}

In this article, we examined teachers' conceptions of the necessary skills and competencies that a teacher should have in early foreign language teaching. The participants of this study were subject teachers (specialized in the foreign language), class teachers (generalists without studies in the foreign language or language education), or teachers with a dual qualification as class teacher and subject teacher. The participants emphasized several different skills and competencies that are important for an early foreign language teacher to have, but only some of the skills were such that all or almost all teachers brought up. We identified seven different categories of skills and competencies, but the different types of teachers were in agreement in only three of them. These were: Enthusiam and ability to inspire; Focus on children and the learning environment; and Skills for early years pedagogy. Thus, the most important aspects were teachers' personal qualities before skills for pedagogy.

The teachers in this study considered it the most essential that early foreign language teachers have enthusiasm and a will to teach a foreign language to young students, and that they are able to inspire and motivate students to language learning. These competencies have been found central in other studies as well (e.g., Edelenbos et al., 2006; Nguyen, 2016). Young children can be easily excited to get involved in different activities, and it is important that teachers capitalize on this quality (Johnstone, 2009; Nikolov, 2009). Focusing on the young learners and creating a safe learning environment were also considered important by the teachers. These findings are also similar to ones in earlier literature (e.g.,
Edelenbos et al., 2006; Tragant Mestres \& Lundberg, 2011). When teachers are able to connect to their students' life worlds, they can create a more suitable and invigorating classroom climate for the students (Edelenbos et al., 2006). A safe learning environment can also provide better opportunities for students to become confident language users. Almost all the teachers in this study considered skills in early years pedagogy important, as teaching of young children new to school life is different from teaching older children and those who can already read and write. However, although teachers considered skills for early years pedagogy important, less than half of them also mentioned skills for foreign language education. Many studies emphasize the need for foreign language methodology (e.g., Zhetpisbayeva et al., 2016). It is essential that teachers know how to select various age-appropriate and action-based activities to guide and encourage students to use the new language repeatedly in meaningful and engaging ways (Enever, 2015; Mezzi, 2012; Nikolov \& Mihaljević Djigunović, 2011).

All teachers participating in our in-service training were exemplars of active teachers who want to commit to life-long learning. Willingness to develop one's skills was mentioned as an important competency for language teachers, in particular by the majority of the subject teachers. Earlier studies show, however, that not all teachers are interested in investing time and effort into further training even when it is offered (Zhetpisbayeva et al., 2016). Another important competency mentioned by many of teachers was teachers' ability to throw oneself in the job. Nguyen (2016) has found in his study that teachers often capitalize on their creative and artistic skills when they use movement, singing or facial expressions to engage learners. We consider this competency to throw oneself in the job, act silly and have fun in early foreign language teaching related to these creative and artistic abilities.

In relation to the second research question, the teachers were not as unanimous about the necessary language skills for teachers in early foreign language teaching as they were about the other skills and competencies. In general, they felt that it was more important to be motivated about teaching a foreign language and being learner-centered than to possess a high level of language competence. Prior research recommends that teachers should have a sufficiently high command of the foreign language being taught (e.g., Enever, 2015; Graham et al., 2017). However, the majority of the respondents (about 90\%) mentioned that communication in general in the target language is the most important about language skills in early foreign language teaching. The second most important aspect about language skills was possessing competence in basic grammar 
and pronunciation. The participants were in general quite lenient about teachers' language skills and opposing views were also expressed. While some teachers felt that teachers should possess a high level of language skills, some yet mentioned that a teacher new to early foreign language learning could learn the language alongside with the students. The responses show that the participants knew what the reality is. Many class teachers in Finland may have to teach a foreign language in the first grades without prior experience in language education or strong foreign language competence. It is positive to see this kind of a supportive approach towards colleagues. Nevertheless, it raises a concern about educational equality in foreign language learning for all children, which is a core value in Finnish education (Niemi et al., 2016).

It may be contradictory that the teachers in this study want teachers to be able to communicate in the foreign language but only require basic grammar and pronunciation from them. In order for a teacher to use the target language for most of the lessons, it requires communicative competence in the language. It is also important for language teachers to use target language at the right level for students. With young learners it means simplified and uncomplicated language (Graham et al., 2017). If teachers only have knowledge about the basics of the foreign language, communicating fluently in the language may be impossible. Moreover, cultural aspects should be integrated to teaching a foreign language, but these might be left out if a teacher is not knowledgeable about them. Cultural aspects received little attention in our data as well. It is also necessary to keep in mind that prior research shows that students whose teachers have a high language proficiency in the foreign language will benefit from it and learn the new language better (Graham et al., 2017; Unsworth et al., 2015). Finland prides on ensuring equal opportunities and equal access to high-quality education to all students (Niemi et al., 2016). In order for it to be realized in early foreign language teaching, further education should be guaranteed for and required of all those teachers who are made to teach a foreign language without sufficient language and cultural skills or knowledge of appropriate language learning activities for young learners. Language skills are not something that a person can acquire from a single in-service teacher training course, though, but they take years of practice to learn.

The findings of this study suggest that the subject teachers were the most active in considering the necessary skills and competencies for an early foreign language teacher, while the class teachers had the least requirements. This is also understandable as subject teachers are the ones whose job it has been to teach foreign languages, while class teachers are new at it. However, no clear differences between the different types of teachers could be determined based on our data. Furthermore, the purpose of this study was not to find generalizable results, but to gain an understanding of the skills and competencies that teachers in Finland should have for foreign language teaching in the early grades. The data used for the study consisted of essays completed during in-service teaching training. Had the data collection methods been different, for example, a questionnaire or an interview, slightly different results might have been obtained.

This study also showed that an in-service teacher training for teachers of different educational backgrounds is beneficial as they get a closer look into each other's skills and competencies and learn to appreciate them better. Collaboration between teachers is becoming more necessary to fulfill the objectives of the core curriculum (Finnish National Board of Education, 2016), so joint workshops and trainings can be a springboard to it as well. As early foreign language teaching in Finland is a new phenomenon, there is need to conduct in-class research to learn about the different activities and strategies that class teachers and subject teachers employ to create learner-centered and engaging environments. In addition, it is important to study what methods and techniques help learners to learn the best in order to give them a sound foundation for foreign language learning.

\section{Footnotes}

1. These extracts are quotes from the data and they have been translated from Finnish by the authors.

\section{Acknowledgements}

Open access funded by Helsinki University Library.

\section{References}

Braun, V., \& Clarke, V. (2006). Using Thematic Analysis in Psychology. Qualitative Research in Psychology, 3(2), 77-101. https://doi. org/10.1191/1478088706qp063oade Wolf, S. Smit, N., \& Lowie, W. (2017). Influences of early English language teaching on oral fluency. ELT Journal Volume, 71(3), 341-353. https://doi.org/10.1093/ elt/ccw115

Dolean, D. D. (2015) How early can we efficiently start teaching a foreign language?, European Early Childhood Education Research Journal, 23:5, 706-719, https://doi.org/10.1080/135029 $3 \times .2015 .1104047$ 
Edelenbos, P., R. Johnstone, \& A. Kubanek. (2006). The Main Pedagogical Principles Underlying the Teaching of Languages to Very Young Learners. Languages for the Children of Europe: Published Research, Good Practice and Main Principles. European Commission. https://ec.europa. eu/assets/eac/languages/policy/languagepolicy/documents/young_en.pdf

Education Statistics Finland (2020a). Perusopetuksen 1-6 luokkien A-kielivalinnat. [Selection of A-languages in grades 1-6 in basic education.] Vipunen. Statistics Finland, the Ministry of Culture and Education and the Finnish National Agency for Education.

Education Statistics Finland (2020b). Perusopetuksen 7-9 luokkien B2-kielivalinnat. [Selection of B2languages in grades 7-9 in basic education.] Vipunen. Statistics Finland, the Ministry of Culture and Education and the Finnish National Agency for Education.

Enever, J. (2015). The Advantages and Disadvantages of English as a Foreign Language with Young Learners. In J. Bland (Ed.), Teaching English to Young Learners: Critical Issues in Language Teaching with 3-12 Year Olds (pp. 13-29). Bloomsbury Academic. https://doi. org/10.5040/9781474257145

Enever, J. (2016). What can we expect of an early start to foreign language learning in Europe today? Gyermeknevelés, 4(1), 2-10.

Finnish Ministry for Education and Culture. (2018). Valtioneuvosto päätti peruskoulun tuntimäärän kasvattamisesta - kieltenopetus alkaa jatkossa jo ensimmäiseltä luokalta [The government decided about the increase of lesson hours in basic education - language learning will start in grade 1.]. Website of the Ministry for Education and Culture. https://minedu. fi/-/valtioneuvosto-paatti-peruskouluntuntimaaran-kasvattamisesta-kieltenopetusalkaa-jatkossa-jo-ensimmaiselta-luokalta

Finnish National Board of Education. (2016). Finnish National Core Curriculum for Basic Education 2014. Publications 2016:5.

Finnish National Board of Education. (2020). Amendments and additions to the National Core Curriculum for Basic Education 2014 regarding the instruction of the A1 language in grades 1-2. Regulations and guidelines 2019:1c.
Graham, S., Courtney, L., Marinis, T., \& Tonkyn, A. (2017). Early Language Learning: The Impact of Teaching and Teacher Factors. Language Learning, 67(4), 922-958. https://doi.org/10.1111/ lang.12251

Hahl, K., Savijärvi, M. \& Wallinheimo, K. (2020). Varhennetun kieltenopetuksen käytäntöjä: opettajien kokemuksia onnistumisista ja haasteista [Practices in early language teaching: Teacher's experiences of success and challenges]. In R. Hilden \& K. Hahl (Eds.), Kielididaktiikan katse tulevaisuuteen: Haasteita, mahdollisuuksia ja uusia avauksia kielten opetukseen [Language didactics looking into the future: Challenges, opportunities and new perspectives to language teaching] (pp. 77103). Ainedidaktisen tutkimusseuran julkaisuja. University of Helsinki.

Han, Z.H. (2013). Forty years later: Updating the Fossilization Hypothesis. Language Teaching, 46(2), 133-171. https://doi.org/10.1017/ S0261444812000511

Harjanne, P., Díaz Larenas, C., \& Tella, S. (2017). Foreignlanguage teaching and studying in Chilean and Finnish classrooms as seen by teachers. Journal of Language and Cultural Education, 5(3), 1-21. https://doi.org/10.1515/jolace-2017-0025

Huhta, A. \& Leontjev, D. (2019). Kieltenopetuksen varhentamisen kärkihankkeen loppuraportti [The final report for the key project in early foreign language teaching]. Centre for Applied Sciences. University of Jyväskylä, Finland. https:// www.jyu.fi/hytk/fi/laitokset/solki/tutkimus/ julkai-sut/pdf-julkaisut/kieltenopetuksenvarhentamisen-karkihankkeen-seu-rantapilottiloppuraportti.pdf

Inha, K. (2018a). Finland invests in early language learning. Retrieved 20 April, 2021 from: https:// www.oph.fi/sites/default/files/documents/ finland_invests_in_early_language_learning. pdf

Inha, K. (2018b). Vuosi kärkihanketta takana [A year of key project behind]. Kieli, koulutus ja yhteiskunta, 9(4). https://www.kieliverkosto.fi/fi/journals/ kieli-koulutus-ja-yhteiskunta-kesakuu-2018/ vuosi-karkihanketta-takana

Inha, K., \& Kähärä, T. (2018). Introducing an earlier start in language teaching: Language learning to start as early as in kindergarten. Retrieved 20 April, 2021 from: https://www.oph.fi/sites/default/ files/documents/introducing_an_earlier_start_ in_language_teaching.pdf 
Johnstone, R. (2009). An early start: What are the key conditions for generalized success? In Enever, J. Moon \& U. Raman (Eds.), Young Learner English Language Policy and Implementation: International Perspectives (pp. 31-41). IATEFL Young Learner Special Interest Group.

Luz Celaya, M. (2012). "I wish I were Three!": Learning EFL at an early age. In M. G. Davies \& A. Taronna (Eds.), New Trends in Early Foreign Language Learning: The Age Factor, CLIL and Languages in Contact. Bridging Research and Good Practices (pp. 2-11). Cambridge Scholars Publishing.

Mezzi, T. (2012). Being young, being adult: The age factor issue for vocabulary in FL education. In M. G. Davies \& A. Taronna (Eds.), New Trends in Early Foreign Language Learning: The Age Factor, CLIL and Languages in Contact. Bridging Research and Good Practices (pp. 12-23). Cambridge Scholars Publishing.

Meriläinen, M., \& Piispanen, M. (2019). The Early Bird Gets the Word. International Electronic Journal of Elementary Education, 12(1), 11-17. https://doi. org/10.26822/iejee.2019155332

Muñoz, C. \& Singleton, D. (2018). Lecture 8: Age and multilingualism. In L. Aronin \& D. Singleton (Eds.), Twelve lectures on multilingualism (pp. 213-230). Multilingual Matters.

Niemi, H., Toom, A., \& Kallioniemi, A. (Eds.) (2016). Miracle of Education: The Principles and Practices of Teaching and Learning in Finnish Schools. $\left(2^{\text {nd }}\right.$ revised edition). Sense Publishers.

Nikolov, M. (2009). The age factor in context. In M. Nikolov (Ed.), The Age Factor and Early Language Learning (pp. 1-37). De Gruyter. https://doi.org/10.1515/9783110218282

Nikolov, M., \& Mihaljević Djigunović, J. (2011). All shades of every colour: an overview of early teaching and learning of foreign languages. Annual Review of Applied Linguistics, 31, 95-119.

Nguyen, C. D. (2016). Metaphors as a window into identity: a study of teachers of English to young learners in Vietnam. System 60, 66-78. https:// doi.org/10.1016/j.system.2016.06.004.

Pfenninger, S. E. \& Singleton, D. (2017). Beyond age effects in instructional L2 learning: Revisiting the age factor. Multilingual Matters.

Pinter, A. (2017). Teaching young learners. Oxford University Press.
Tragant Mestres, E., \& Lundberg, G. (2011). The teacher's role: what is its significance in early language learning? In Enever, J. (Ed.), Early Language Learning: Evidence from the ELLIE study (pp. 81-100). British Council. https://www. teachingenglish.org.uk/sites/teacheng/files/ B309\%20ELLiE\%2OBook\%202011\%2OFINAL.pdf

Unsworth, S., Persson, L., Prins, T., \& De Bot, K. (2015). An investigation of factors affecting early foreign language learning in the Netherlands. Applied Linguistics, 36(5), 527-48. https://doi.org/10.1093/ applin/am+052

Zhetpisbayeva, B. A., Shelestova, T. Y., \& Abildina, S. K. (2016). Examining teachers' views on the implementation of English as L3 into primary schools: A case of Kazakhstan. International Electronic Journal of Elementary Education, 8(4), 659-674. 